\title{
DERIVATION AND AFFIXATION PROCESS IN SPEECH OF DANANJAYA HETTIARACHCHI
}

\author{
Susilawati ${ }^{1}$, Fennia Bintari Putri ${ }^{2}$ \\ ${ }^{1}$ IKIP SILIWANGI \\ ${ }^{2}$ IKIP SILIWANGI \\ ${ }^{1}$ susilawati1375@gmail.com, ${ }^{2}$ fenniabintariputri1@gmail.com
}

\begin{abstract}
This journal discussed about the derivation and affixation process in English speech. Derivation is one type of linguistics morphology that involved word formation, and there are affixes used to construct new word. The aims is to analyzed what kinds of derivation and affixation mostly used on Dananjaya Hettiarachchi speech (I See Something). The data are all words containing derivation and affixation that found in Dananjaya Hettiarachchi Speech entitled I See Something. The descriptive qualitative method used to analyze the data. The technique of data collecting is documentation from https://www.linkedin.com/ accessed on May 23, 2018. From the data collection, the researchers found that adjective formation is the mostly used in the derivational process, which consist of 6 variations in 13 words. The second is noun formation, which consist of 3 variations in 12 words. The third is adverb formation, which consist of 3 variations in 3 words. And the last is verb formation, which consist of 2 variations in 2 words. While the affixes that mostly used is suffix, which consist of 11 suffixes used. The second is prefixing only 1 prefix used. And the researchers didn't found infix on the speech text.
\end{abstract}

Keywords: Derivation, Affixation, Process, Speech.

\section{INTRODUCTION}

Language is important in life is used as a means of communication or interaction to convey ideas, thoughts, goals and purpose to others. According to (Hazen, 2015) "the human combinatorial system use most for communication is language". Through language we can find out all the information we need either oral or writing language. Therefore, we should master the language and the elements of it, such as vocabulary, structure, and the others. It's already been a human nature to always interact and communicate with the environment. They interact using a variety of languages, whether written language, gestures, or spoken language commonly used. Communication won't work properly if people don't comprehend what is spoken by the speaker to the hearer, so it would leads misunderstandings in communicating. When someone wants to communicate with others, he must have many vocabularies, in order to make the communications running smoothly and easily understandable.

Unfortunately, in the languages, especially the foreign language, most people can't develop the vocabulary from one word to another word. For examples:

Table 1. Derivational process

\begin{tabular}{lll}
\hline \multicolumn{1}{c}{ Word Class } & Affixation & \multicolumn{1}{c}{ New Word Class } \\
\hline $\begin{array}{l}\text { Communicate } \\
\text { (verb) }\end{array}$ & -ion & $\begin{array}{l}\text { Communication } \\
\text { (noun) }\end{array}$ \\
\hline Sad (adjective) & -ness & Sadness (noun) \\
\hline
\end{tabular}

Table 2. Inflectional process 


\begin{tabular}{lll}
\hline \multicolumn{1}{c}{ Word Class } & Affixation & \multicolumn{1}{c}{ New Word Class } \\
\hline Table (noun) & - s & Tables (noun) \\
\hline Play (verb) & -ing & Playing (verb) \\
\hline
\end{tabular}

Table 3. Affixation Process

\begin{tabular}{cc}
\hline Prefix & Suffix \\
\hline Re-wind & Happi-ly \\
\hline
\end{tabular}

In this case, sometimes a person feel confused to translate a word after the word structure is changing, besides that they also do not know the word contains parts of speech. Communication sometimes does not run smoothly, someone can be wrong in receiving understanding from talking with the hearer simply because they don't know the meaning of some words they say. A word is a language package containing both form and meaning (Hazen, 2015). When we have lack of the vocabulary in foreign language, it can make difficulty to understand the meaning of the language itself. But if they know the derivational process, it could increase their vocabulary knowledge in communicating, so the misunderstandings that may occur can be avoided. In addition it will help everyone learns English easily.

This unfortunate is given the importance of the role of language skills that are able to support success in communicating. For that case, it needs more attention about learning linguistics. According to (Asgari, 2012) has stated "Linguistics is a scientific research into all aspects of human language, there is a specialize branch for each approach to the examination of language". One of the branches of linguistics is morphology, the study about words arrangement. As stated by (Aronoff \& Fudeman, 2011) "in linguistics morphology refers to the mental system involved in word formation or to the branch of linguistics that deals with words, their internal structure, and how they are formed". In morphology, there is a new word formed from a word added by the so-called derivational morpheme.

In learning English, someone has to know 8 parts of speech i.e. verbs, nouns, adjectives, adverbs, pronouns, prepositions, conjunction, and interjections. But in derivation, someone just had to know only 4 classes parts of speech i.e. noun, verb, adjective, and adverb.

Particularly, the researchers are interested to analyze what kinds of derivational process and what kinds of affixation are mostly used on Dananjaya Hettiarachchi speech (I See Something). Derivational and affixation are part of morphological process which focuses on word structures or word formation.

Furthermore, (Aronoff \& Fudeman, 2011) has stated "morphology is a distinct component of languages or grammars". As the foreign language learners, morphology is making us easier to differ the component of words or the structure of words in detail. In other way, we can say "a study about the structures in words is called morphology" (Haspelmath \& Sims, 2010) morphology study of the ins and outs of word forms as well as the function changes the word form, it can leads to misunderstanding in the words meaning. But, we can avoid it if we understand the word form well.

In relation to the linguistic, what was learned in morphology is a form of the word. In addition, changes in the shape of words and meanings that appears and changes the words class that caused by the change of the form of that word, also became the object of 
conversation in morphology. In other words, structurally object discussion in morphology is a morpheme at the lowest level and at the highest level. "The smallest element of a meaningful and identifiable word is called morpheme. For example in nut-s, both $-\mathrm{s}$ and nut are morphemes" (Haspelmath \& Sims, 2010)

According to (Trabant \& Ward, 2001) there are two branches of morphology, the first is inflectional morphology, and the second is lexical or derivational morphology.

\section{Inflectional morphology}

Inflectional morphology is relations among word-forms in lexeme. (Haspelmath \& Sims, 2010). Lexemes can be notion as sets of word-forms, and each word-form be owned by one lexeme. The word-forms live, lives, lived, and living all belong to the lexeme live (Haspelmath \& Sims, 2010). Its mean that inflectional morphology is a process that only changes the grammatical function, does not build a new word form.

According to (Aronoff \& Fudeman, 2011) Inflection involves the formation of grammatical forms - past, present, future; singular, plural; masculine, feminine, neuter; and so on - of a single lexeme. In English, regular verb lexemes own a lexical stem, which is the bare form with no affixes (e.g., select) and three more inflected forms, one each with the suffixes -s, -ed, and -ing (selects, selected, and selecting). One of the ways inflection could be realized is through affixes. The examples of words + inflectional morphemes (Aronoff \& Fudeman, 2011) are:

Table 4. Inflectional Morphology

\begin{tabular}{ccc}
\hline No & Nouns & Verbs \\
\hline 1 & Book $+\mathrm{s}$ & Read $+\mathrm{s}$ \\
\hline 2 & Fox + es & Load + ed \\
\hline 3 & & See + n \\
\hline 4 & & Drink + ing \\
\hline
\end{tabular}

\section{Lexical or derivational morphology}

According to (Aronoff \& Fudeman, 2011) "derivation generally results in a change in lexical meaning or the lexical category of a particular word". In addition, derivation is one of the process how a new word can be formed, for example words: "achieve-ments" and "achiev-ed" derive from "achieve".

A process in word formation through affixation which results new lexeme is called derivation. Affixation may involve prefixes, suffixes, infixes, and perhaps circumfixes (Aronoff \& Fudeman, 2011).

- A prefix is attached in front of the base

- A suffix is attached to the end of its base

- An infix is attached in the midst of its base

- A Circumfix 
The examples of words + derivational affixes:

Table 5. Derivational Morphology

\begin{tabular}{ccc}
\hline $\begin{array}{c}\text { Nouns to } \\
\text { adjectives }\end{array}$ & Verbs to nouns & $\begin{array}{c}\text { Adjectives to } \\
\text { adverbs }\end{array}$ \\
\hline Hawk + ish & $\begin{array}{c}\text { Discombobulat }+ \\
\text { ion }\end{array}$ & Sad + ly \\
\hline Poison + ous & Acquitt + al & Efficient + ly \\
\hline Soul + ful & Digg + er & \\
\hline Iron + like & & \\
\hline
\end{tabular}

There are some derivational processes in (Efransyah, 2016).

Table 6. Derivational Processes in Efransyah

\begin{tabular}{|c|c|c|c|}
\hline $\begin{array}{l}\text { To Form } \\
\text { Verb }\end{array}$ & To Form Noun & To Form Adjective & $\begin{array}{c}\text { To Form } \\
\text { Adverb }\end{array}$ \\
\hline $\begin{array}{l}\text { 1. Noun + } \\
\text { ate / ize/ fy. } \\
\text { Example: } \\
\text { Facilitate, } \\
\text { Memorize, } \\
\text { Beautify. } \\
\text { 2. Adjective + } \\
\text { ize / fy / en. } \\
\text { Example: } \\
\text { Legalize, } \\
\text { Identify, } \\
\text { Brighten. }\end{array}$ & $\begin{array}{l}\text { 1. Verb + } \\
\text { age / ance / ment / ing } \\
\text { / (ion/tion) / ure / al / } \\
\text { (er/or/ar/ee). } \\
\text { Example: } \\
\text { Carriage, Allowance, } \\
\text { Agreement, Building, } \\
\text { Calculation, } \\
\text { Exposure, Arrival, } \\
\text { Trainer. } \\
\\
\text { 2. Adjective + } \\
\text { ce / cy / ity / th / ness. } \\
\text { Example: } \\
\text { Importance, Privacy, } \\
\text { Simplicity, Length, } \\
\text { Dryness. } \\
\text { 3. Noun + } \\
\text { hood / ship / ism / cy / } \\
\text { (er/ian/ist /ster). } \\
\text { Example: } \\
\text { Brotherhood, } \\
\text { Friendship, } \\
\text { Capitalism, } \\
\text { Advocacy, Gangster. }\end{array}$ & $\begin{array}{l}\text { 1. Noun + } \\
\text { y / ful /al / ar / less / } \\
\text { ary / ic / ish / en / } \\
\text { ed / ous / like. } \\
\text { Example: } \\
\text { Dirty, Merciful, } \\
\text { Regional, Consular, } \\
\text { Careless, } \\
\text { Legendary, } \\
\text { Democratic, } \\
\text { Bookish, Golden, } \\
\text { Haired, Famous, } \\
\text { Homelike. } \\
\\
\text { 2. Verb + } \\
\text { able / ous / ent / ive } \\
\text { / ing / ed / ful / less. } \\
\text { Example: } \\
\text { Manageable, } \\
\text { Infectious, } \\
\text { Different, Creative, } \\
\text { Lasting, Collecteed, } \\
\text { Useful, Sleepless. }\end{array}$ & $\begin{array}{l}\text { Adjective } \\
+ \\
\text { ly / ably / } \\
\text { fully. } \\
\text { Example: } \\
\text { Generally, } \\
\text { Sensibly, } \\
\text { Faithfully. }\end{array}$ \\
\hline
\end{tabular}

\section{Speech}

Speech is universal - very community of human beings has a fully developed spoken language (Liberman, 1996). The examples of popular speech are: Obama Speech, Donald Trump speech, and Dananjaya Hettiarachchi speech. The researchers choose speech text to be analyzed because speech shows someone speaking ability, where speaking ability resulted by the rich of vocabularies and it can't be separated from the derivational process. 


\section{METHOD}

This research analyzed the derivational process in speech text of Dananjaya Hettiarachchi entitled "I See Something". The researchers use the review document to get information. The purpose of this study are to find out what kinds of derivational process and affixation are mostly used on Dananjaya Hettiarachchi speech (I See Something). In this research we used qualitative research design. According to (Kaswan \& Suprijadi, 2016) "A qualitative research design is a research design that places primary important on studying small samples of purposely chosen individuals; not attempting to control contextual factors, but rather seeking, through various methods, to understand things from the informants' points of view; and creating a rich and in-depth picture of the phenomena under investigation".

\section{RESULTS AND DISCUSSION}

The data collection of this research was taken from the speech text below:

\section{Dananjaya Hettiarachchi - Speaker, trainer and HRD specialist “I SEE SOMETHING”}

You and I aren't very different from this flower. Just like this flower is unique, you are unique. All of us have something special that makes us as beautiful. Do you know what makes you special? Now the answer to that can be a little difficult of find, because sometimes life has a cruel way of picking out your petals, breaking you in two and throwing you into the trash. Now when you're broken, it's very difficult to feel special. Mr. Contest Chair, my fellow flowers. I can remember the first time I broke. I was 17 years old. I had already flunked high school and managed to get myself arrested. Now, I wasn't afraid of the cops, but there was one person I was very afraid of and that was my mama. Raise your hand if you have an emotional mother. Let me see. Put them all together you get my mama. I can hear her scream outside the police station; even the cops were afraid. She came up to me, held the iron bars, looked into my eyes and I saw a tear coming down her face. Now I've seen my mama cry before, but mothers cry three types of tears: tears of joy, tears of sorrow and tears of shame. And when a son sees a mother cry tears of shame, that's a life changing moment. She looked at me and said "Son, I want you to be a better man". That night, when I drove home, my dad was waiting for me at home. Now, my dad is a cool dad. Raise your hand if you have a cool dad. Put them all together you get my dad. My dad came up to me and said "Son, it's OK. You flunked your exams. You already got arrested. That's fine. You get that from your mother side. I want you to start working immediately". And I said, 'OK.' So my dad took me to meet one of his friends called Sam. Now, Sam was an accountant who had an accounting firm and had generously decided to make me his personal assistant, and there he was. He looked like a teddy bear, but this man was special. I looked at him and he looked at me, and then he said the most amazing thing. He said "Son, I see something in you, but I don't know what it is. If you decide to work with me, I can help you find that something". And I was like, wow! That's the first time in my whole life somebody has ever told they see something in me. And I started working for Sam. And every day after work he used to tell me stories about the world, about history, about culture, about philosophy and it was much more interesting than what I learned in school. And I discovered I can dream and I started dreaming, ladies and gentlemen. After one year I went back into high school, completed my exams and went into college. After successfully completing college, I found a great girl, but not a job. I didn't know what I wanted to do with my life. Have you ever had that problem? And when you're lost, it's difficult to feel special. So I went back to my cool dad and I said "Dad, I feel lost". 
He said, "You are like your mother". So my dad introduced me to this strange club that had a strange name, with strange people, talking. On the first meeting they told me to do something called a table topic. I aced it. But while I was speaking I see a strange man seated in the back row, humble, simple, the unfailing quality of kindness in his eyes. As soon as I finished, he walked up to me, looked me dead straight in the eye and said, "Son, I see something in you, but I don't know what it is. If you come here twice a month maybe we can find that something". And ladies and gentlemen, I discovered I could speak and I love speaking and that led me to become a teacher. I know what it's like to not have enough money in your bank account. I know what it's like to worry when the bills start coming in. And sometimes in the middle of the night, I wake up my beautiful wife and ask her "Honey, why did you marry me?". She says, "I saw something in you, but I still I don't know what it is?" Ladies and gentlemen, today I'm a dreamer, I'm a speaker and I learned the unfailing quality of unconditional love from my wife. I was broken and I've been broken, lost and broke many

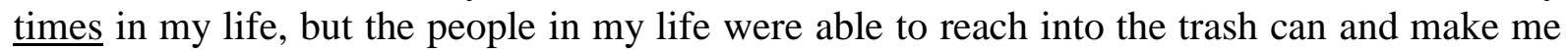
whole again. If it was up to me, I would have never been able to do that. And this is why if you have great people in your life, no matter how broke, how lost or how broken you become they can piece you back together. Ladies and gentlemen, when I look at you I see something in you, but I don't know what it is? Over to you.

From the text above the researchers analyzed the derivational process found from the text as follows:

Table 7. To Form Adjective

\begin{tabular}{lll}
\hline No & Pattern & Finding \\
\hline 1 & Noun + ed & Seated \\
\hline 2 & Noun + ful & Beautiful \\
\hline 3 & Noun + al & Emotional, Unconditional \\
\hline 4 & Verb + ed & $\begin{array}{l}\text { Called, Decided, Used, Learned, Discovered, } \\
\text { Finished }\end{array}$ \\
\hline 5 & Verb + ing & Interesting, Unfailing \\
\hline 6 & Verb + ent & Different \\
\hline
\end{tabular}

Table 8. To Form Noun

\begin{tabular}{lll}
\hline No & Pattern & Finding \\
\hline 1 & Verb + ing & $\begin{array}{l}\text { Picking, Breaking, Throwing, Coming, Waiting, } \\
\text { Working, Talking, Meeting, Speaking }\end{array}$ \\
\hline 2 & Verb + er & Teacher, Speaker \\
\hline 3 & Adjective + ness & Kindness \\
\hline
\end{tabular}

Table 9. To Form Adverb

\begin{tabular}{lll}
\hline No & Pattern & Finding \\
\hline 1 & Verb + ly & Immediately \\
\hline 2 & Adjective + ly & Generously \\
\hline 3 & Noun + ly & Successfully \\
\hline
\end{tabular}

Table 10. To Form Verb

\begin{tabular}{lll}
\hline No & Pattern & Finding \\
\hline 1 & Noun + ing & Changing \\
\hline
\end{tabular}




\section{Adjective + ing $\quad$ Completing}

The researchers also analyzed the inflectional process found from the text for comparison with derivational process as follows:

Table 11. Verb

\begin{tabular}{lll}
\hline No & Pattern & Finding \\
\hline 1 & Verb + s & Makes, Cops, Sees \\
\hline 2 & Verb + ed & $\begin{array}{l}\text { Flunked, Managed, Arrested, Looked, Started, } \\
\text { Wanted, Introduced, Walked }\end{array}$ \\
\hline & & Table 12. Noun \\
\hline No & Pattern & Finding \\
\hline 1 & Noun + s & Petals, Flowers, Bars, Eyes, Types, Tears, \\
& & Mothers, Exams, Friends, Bills, Times \\
\hline 2 & Noun + ing & Accounting, Dreaming \\
\hline 3 & Noun + ies & Stories, Ladies \\
\hline 4 & Noun + er & Dreamer \\
\hline
\end{tabular}

Table 13. Adjective

\begin{tabular}{lll}
\hline No & Pattern & Finding \\
\hline 1 & Adjective + ed & Completed \\
\hline
\end{tabular}

Preposition analyzing the derivational process and inflectional process, the researchers also found the affixes used from the text as follows:

Table 14. The affixes used

\begin{tabular}{|c|c|c|c|}
\hline No & Prefix & Infix & Suffix \\
\hline 1 & Un - & & - ent \\
\hline 2 & & & $-\quad S$ \\
\hline 3 & & & - $\quad$ ful \\
\hline 4 & & & - $\quad$ ing \\
\hline 5 & & & $-\quad$ ed \\
\hline 6 & & & - al \\
\hline 7 & & & $-\quad 1 y$ \\
\hline 8 & & & - ies \\
\hline 9 & & & $-\quad d$ \\
\hline 10 & & & - ness \\
\hline 11 & & & - er \\
\hline
\end{tabular}

From the data finding above, the researchers found that adjective formation is the mostly used in the derivational process, which consist of 6 variations in 13 words. The second is noun formation, which consist of 3 variations in 12 words. The third is adverb formation, which consist of 3 variations in 3 words. And the last is verb formation, which consist of 2 variations in 2 words.

The inflectional process that mostly used from the text above is noun formation, which consists of 4 variations in 16 words. The second is verb formation, which consist of 2 
variations in 11 words. And the third is adjective formation, which consist of 1 variation in 1 word. The researchers didn't found adverb formation on the text above.

The affixes that mostly used is suffix, which consist of 11 suffixes used. The second is prefixing only 1 prefix used. And the researchers didn't found infix on the speech text.

\section{CONCLUSION}

Based on the data analysis on speech text of Dananjaya Hettiarachchi entitled "I See Something", the following conclusion can be drawn. As the objectives of this research are to find out what kinds of derivational process and affixation are mostly used on Dananjaya Hettiarachchi speech (I See Something). In this research, the researchers found that adjective formation is the mostly used in the derivational process, which consist of 6 variations in 13 words. The second is noun formation, which consist of 3 variations in 12 words. The third is adverb formation, which consist of 3 variations in 3 words. And the last is verb formation, which consist of 2 variations in 2 words. The researchers also found that the affixes that mostly used is suffix, which consist of 11 suffixes used. The second is prefixing only 1 prefix used. And the researchers didn't found infix on the speech text.

\section{ACKNOWLEDGEMENTS}

The researchers would like to thank to Allah SWT who has given us a power, strength, and health to finish this journal. We want to say thanks to IKIP Siliwangi especially English Education Study Program. The greatest appreciation to Mr. Efransyah for his advices, supervision, and crucial contribution in the improvement of the result of this journal. We are very grateful to have some close friends and family who always support us. This research is far from perfect, but it is expected that it will be useful not only for the researchers, but also for the readers. For this reason, suggestions and criticism to wise are welcomed.

\section{REFERENCES}

Aronoff, M., \& Fudeman, K. (2011). What is morphology-2nd ed. (2nd ed.). United Kingdom: Blackwell Publishing.

Asgari, A. (2012). Linguistics for beginners. Lulu Com.

Efransyah. (2016). Analysis of Derivational Process in Narrative Text Entitled the Legend of Malin Kundang, 161-165.

Haspelmath, M., \& Sims, A. D. (2010). Understanding Morphology 2nd edition.

Hazen, K. (2015). An Introduction to Language.

Hettiarachchi, D. (n.d.). Dananjaya Hettiarachchi - I See Something - | Ibtissam Bazi | Pulse | LinkedIn. Retrieved May 23, 2018, from https://www.linkedin.com/pulse/dananjayahettiarachchi-i-see-something-ibtissam-bazi

Kaswan, \& Suprijadi, D. (2016). Research in English Language Education.

Liberman, A. M. (1996). Speech: A Special Code. Retrieved May 16, 2018, from https://books.google.co.id/books?id=cCivwP1zbfsC \&printsec $=$ frontcover $\& \mathrm{dq}=$ speech $\&$ $\mathrm{hl}=\mathrm{id} \& \mathrm{sa}=\mathrm{X} \& \mathrm{ved}=0 \mathrm{ahUKEwiJz4mW2InbAhUO}$ _WMKHSqSCPoQ6AEIKzAA\#v=one page $\& \mathrm{q}=$ speech is $\& \mathrm{f}=\mathrm{false}$

Trabant, J., \& Ward, S. (2001). New essays on the origins of language. Retrieved from https://books.google.co.id/books?id=wzsdGOI2gyoC\&pg=PR4\&dq=New+Essays $+o n+t$ he+Origin+of+Language+edited+by+Jürgen+Trabant,+Sean+Ward 